\title{
Estimation of pulse transit time using ECG R-wave
}

\author{
脈波伝搬時間の簡便計測法
}

\author{
Nobutada CHIBA, Taisuke IWAGAMI, Masaya SUGIMOTO, Takahito KOUOU, Kenji IKEDA, Kiyoyuki YAMAZAKI \\ and Katsuro OKAMOTO \\ Dept.Bio-Medical Engineening, School of High-Technology for Human Welfare, Tokai University, 317, Nishino, \\ Numazu, Shizuoka, 410-0321, JAPAN \\ TEL:81-559-68-1211(EX4415), FAX:81-559-68-1156 \\ ( Accepted for publication 6 November 1997)
}

In this study an experiment was carried out to establish a convenient method of Pulse Transit Time(PTT) estimation. The time interval between ECG R-wave and PTG( $\tau$ EP) were measured under cooling stimulation and the induced autonomic response was analyzed. ECG R-Wave was used as a reference timing for PTT measurement. It was possible to use the time from ECG R-wave to PTG( $\tau$ EP) as an ergonomic measure.

Keywords:Pulse Transit Time(PTT), ECG R-Wave, PTG

\section{I.INTRODUCTION}

指尖容積脈波を用いた脈波伝搬時間は、心 蔵の負荷状態、血液量、血管の収縮拡張等の 自律神経系の状態を知るのに有用であり、 ${ }^{1,2}$ 普通、心音図と指尖容積脈波の 2 点間におけ る到達時間の差から求められるが、簡便に循 環動態を測定することを考えて、胸壁の振動 の開始時点（心音図）の後に現れる心電図の R波のピークから、指尖容積脈波の立ち上が りまでの時間を脈波伝搬時間とする方法を考 えた。心電図R波を時間軸の基点とし得るか どうかを検討するため、心電図R波と加速度 センサによってとらえた胸壁の振動波形のピー クとの時間差を計測した。

\section{II.EXPERIMENTAL}

被験者は、健常成人 5 名（男性 3 名、女性 2 名、平均 21 歳）とした。被験者に安静 状態を保たせ、胸壁に心電図第II誘導（R波） 及び加速度センサ（胸壁の振動）を、右手第 2 指に光電脈波センサ（脈波の立ち上がり点） を装着した。まず、コントロールとして冷刺 激前 2 分間の波形を記録した。次に、 $0{ }^{\circ} \mathrm{C}$ 5 ～ $\mathrm{C}$ 永水が入ったポリバケツに左手を入れ て手関節が水面直下に没するまで浸し、30
秒間冷刺激を行った。冷刺激後、水水から左 手をあげてから刺激後として、2 分間記録し た。これらは、高感度生体アンプを用いてデ ジタルレコーダに、サンプリング周波数は、 $500 \mathrm{H} \mathrm{z}$ 、精度は土1 V/14 b i t で記録 した。計測デー夕を移動平均法により平滑化 し、パーソナルコンピュータを用いて、心電 図のR波、胸壁の振動（心音図）、脈波の立 ち上がり点を自動的に検出し、胸壁の振動の 開始時点と心電図 R波の間の時間差（TD）、 胸壁の振動開始と脈波の立ち上がり点の間の 脈波伝搬時間（PTT1）、R波と脈波（PTT2) の立ち上がり点までを求め、脈波伝搬時間を 算出した。

\section{III.RESULTS \& DISCUSSION}

Figure1は、被験者 5 人についてTDの平均值、 標準偏差を示した。冷刺激前と刺激中、刺激 中と刺激後、刺激前と刺激後のいずれにおい ても有意な差は認められず、全ての場合の平 均のTDは0.013(秒)であった。Figure2に、冷 刺激前、刺激中、刺激後のPTT2の平均及び標 準偏差を示した。冷刺激前と冷刺激中では有 


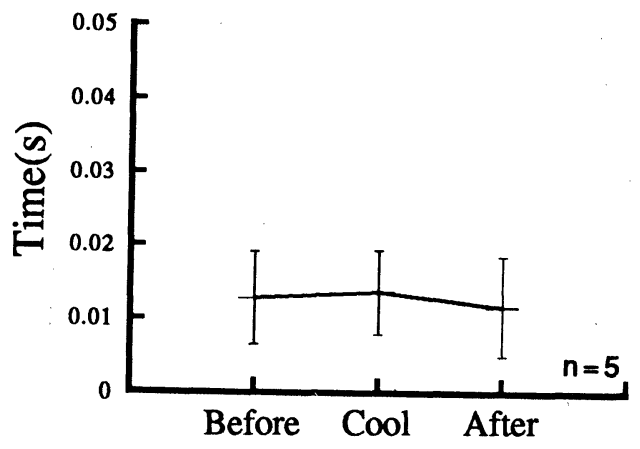

FIG.1 Time delay of onset of breast vibration from ECG R-wave in each condition.

意な脈波伝搬時間の減少 $(\mathrm{p}<0.01)$ が見られた。 冷刺激中と冷刺激後では有意な脈波伝搬時間 の増加( $\mathrm{p}<0.05)$ が見られた。冷刺激により短 縮した脈波伝搬時間は0.012(秒)程度であった。 冷刺激前と冷刺激後は有意な差は認められず、 刺激によるPTT2の減少は速やかに回復したと 考えられる。冷刺激により短縮した脈波伝搬 時間は0.014(秒)程度であった。以上より、TD、 PTT1およびPTT2の関係は、PTT1 = TD+PTT2 である。本実験で示されたように、刺激負荷 による脈波伝搬時間が、変化するときTDがほ は一定であるので、PTT1の測定はPTT2の測 定で代用できる。

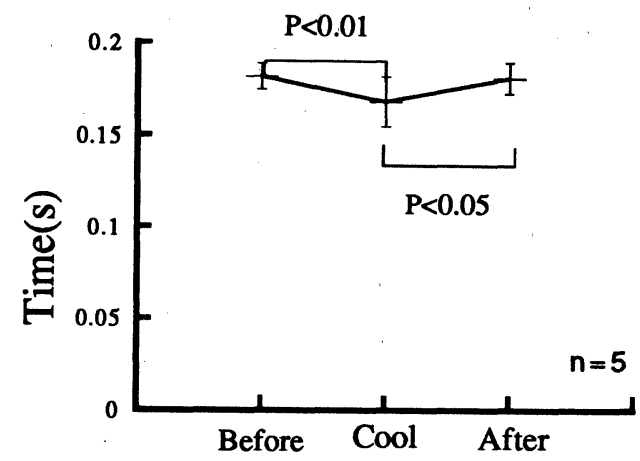

FIG.2 ECG R-wave based PTT.

\section{REFERENCES}

1 Keiko Nagasima, Kiyotaka Hoshiai, Masami Suganuma, Nao Yonehana,

Kiyoyuki Ymazaki, Katsuro Okamoto, Takashi Itoh and Haruka Okino., Experimental study on an Evaluation Technique of Autonomic Function Using Plethysmography, The Bulletin of School of High-Technology for Human Welfare Tokai University.Vol.4,1994.

2 Toshiyo.Tamura, Takumi Yosimura, Wen-Xi Chen, Tatsuo Togawa., Changes in pulse Wave Transit Time and Blood Pressure during Bathing, Reports of the Institute for Medical \& Dental Engineering 29, 104 109 (1995)

'97 SAS Intelligent Symposium 